\title{
Determinants of Urban Poverty in Muklami Town of West Wellega Zone of Oromia, Ethiopia
}

\author{
Debeli Chala Biyena \\ Forest and Range Land Directorate, Ethiopian Biodiversity Institute, Ethiopia
}

\begin{abstract}
Ethiopia is known all over the world where citizens live in very chronic condition of poverty. Urban poverty has been given less attention on research and development agenda of Ethiopia and particularly, for medium towns like Muklami. The purpose of this study is to measure the magnitude and identify determinants of poverty in Muklami town. Both primary and secondary data sources were use. A cross-sectional survey 143 household heads were carried-out by a using proportional random sampling method. To calculate total poverty line, a Cost of Basic Needs $(\mathrm{CBN})$ approach was utilized. In addition both simple descriptive statistics and econometrics model such as Logit model were employed to analyses the data. The result to the study shows that head count poverty, poverty gap and severity of poverty indices are $35.6 \%, 12.7 \%$, and $50.8 \%$, respectively. The variables that are positively correlated with the probability of being poor are: sex, family size, health status, and house tenure. Variables negatively correlated with the probability of being poor are: income, educational level, marital status, age, employment status, saving habit, water source, and access to credit. Based on the result of the study, the following recommendation was made. Efforts should be made to raise the real income of households through well-paying and steady job creation by the setup of micro and small scale enterprises, with the increased provision of economic and social infrastructure of houses, education, and better water sanitation services for poverty reduction.
\end{abstract}

Keywords: Urban Poverty, Cost of Basic Needs, Logit model and Muklami town

DOI: $10.7176 / \mathrm{JRDM} / 57-01$

Publication date:July $31^{\text {st }} 2019$

\subsection{Background of the study}

Poverty has been considered as the condition that is said to exist when people lack the means to satisfy their basic needs such as food, shelter and clothes. For instance, World Bank has defined poverty as "the inability to attain a minimum standard of living" (World Bank, 20007). Poverty is a pervasive reality of the world. It is a world's greatest challenge in the 21 st century. Based on estimates of international poverty lines, national population live on less than $\$ 1.25$ a day), 12 countries managed to reduce poverty levels between 1990 and 2005. Although these declines are encouraging, they still leave a large proportion of the total population living in extreme poverty, and all 19 countries face major challenges in meeting the 2015 Millennium Development Goal target(World Bank , 2013). Based on the national poverty line of the year 1999, 44 percent of the population is absolutely poor (MoFED, 2002). Most of the population lives in extreme poverty. World Bank (2006), for instance, reports that $23 \%$ of the population survives on less than $\$ 1.25$ a day and $77.8 \%$ live on less than $\$ 2$ a day.

In Africa, particularly Sub Saharan Africa (SSA) economic performance has been markedly worse than that of other regions. The great majority of Africans live on barely $\$ 0.65$ a day and this number is decreasing relentlessly (WB, 2000). The rural poor accounts for $80 \%$ of African poverty, while, urban poverty is substantial and appears to be growing. People in SSA are among the poorest in the world both in real incomes and in access to social services. 300 million people in Sub-Saharan Africa, almost half the region's population, live on less than $\$ 1$ a day (UNDP, 2006).

Ethiopia is one of the world's poorest countries by any standards. It is known all over the world where citizens live in very chronic condition of poverty Poverty and low level of welfare is widespread in Ethiopia. According to official sources (MoFED, 2007), This could be while urban life is complex and is predominantly monetized economy that of rural is basically determined by assets on land, number of oxen, cows, sheep, goats, extra available to the farmer. The incidence of urban poverty measured by the headcount index in 1995/96 was 51.6\%. That is, more than half of the population was poor in 1995/1996. While this share of the poor declined to $38.5 \%$ in $2004 / 05$ (see also Tassew et al., 2008; Bigsten et al., 2005), the country is still in the lowest rank as compared to other countries based on both human development and poverty indices.

The Human Poverty Index (HPI-1) focuses on the proportion of people below a threshold level in the same dimensions of human development as the HDI such as living a long and healthy life, having access to education, and a decent standard of living (based on the $\$ 1.25$ a day poverty line at PPP poverty measure). It is $31 \% \%$ for Ethiopia's HDI value for 2014 is 0.44 which put the country in the low human development category positioning it at 174 out of 188 countries and territories (http://hdr.undp.org,Warld bank,2015).

Food insecurity is a defining characteristic of poverty with up to 10 million people dependent on humanitarian assistance. The country has the lowest GNP per capita in the world. Its purchasing power parity (PPP) adjusted GNP is ranked 200th out of 206 countries (WB, 2006).The HDI ranked Ethiopia the 91 st out of 94 developing 
countries(ibid).According to the recent official estimate of the country the overall incidence of poverty is around 38.7\% (Plan for Accelerated and Sustainable Development to End Poverty(PASDEP),2006). Even though the government of Ethiopia has tried to address some problems related to poverty, the focus given to urban area are not gone with the extent of the problem.

High population growth due to migration and other internal factors have making life hard in urban Ethiopia. This really can lead to high crime, strikes and other socio economic and political problems. Therefore, the issues addressed in this study can help the government to design strategies to tackle the real problem of urban areas in general and the study area in particular.

In Ethiopia, studies show that urbanization is growing at a faster rate. According to Ministry of works and Urban Development(MWUD),(2006), there are above 925 urban centers at different growth stages in Ethiopia and annual urban population growth rate is estimated to be above $4.84 \%$ (W0rld bank in 2014). This rate depicts that the population of urban areas is increasing by a half million people every year. Today, the population of urban centers is about 12 million and this comprises $16 \%$ of the total population of the country. The total urban population of the country will be 17.8 million by 2015 and 22 million by 2020 . The combination of urban growth that is amongst the highest in the world with the high prevalence of urban poverty suggests a rapidly growing number of urban poor (PASDEP, 2006).

Given the above figure, the government of Ethiopia pursued urban development strategy including medium and small size towns on the second phase of Poverty Reduction Strategic Paper (PRSP) (2006-2010) called Plan for Accelerated and Sustainable Development to End Poverty (PASDEP) than the first phase of PRSP. However, still gives mere weight on rural development. In addition to giving less attention to urban issues, the major weakness of the first phase of PRSP was its lack of detail information for implementation and monitoring the strategy as cited in (Esubalew, 2006). This problem now incorporated in PASDEP. However, to emphasized on sector strategies rather than having specific policy for directing strategies and achieving goals and objectives.

This paper should help to reexamine urban poverty reduction strategy and goals in the city and for medium size towns by way of analyzing its determinants. The fundamental question that comes in the fore front is who are poor and what factors determine to be poor. Therefore, the issues addressed in this study can help the government to design strategies to tackle the real problem of urban areas in general and the study area in particular.

\section{Methodology of the study}

The study was conducted in west wollega zone, BojiChekorsa woreda of Muklami town.This town is located at distance of $57 \mathrm{~km}$ from the zonal town Ghimbi and about $498 \mathrm{~km}$ from the capital city of Ethiopia, Addis Ababa. The town has two main climatic seasons. These particular and much known seasons are dry and wet. The dry season is from the month of October through May, and the wet season is from June through September in the town. The average annual temperature of the town is estimated to $17 \mathrm{c}^{0}$. But, the town receive annual range of rainfall from $1800 \mathrm{~mm}$ to $2200 \mathrm{~mm}$. Muklami town has a population of 12247 of which 6289 are male and 5958 female and 3240 households. In the town there is an access to education service, health service, water supply service, electricity service and communication services. But, these services had poorly provided to the society. According to the city administration office, the main economic activities of Muklami town are service provision, petty trade, handcrafts/cottages and urban agriculture. Agriculture is the main economic activity and the common agricultural products are maize, teff, sorghum, coffe. The town has one health center, three private clinics, one primary school (grade 1-8), one secondary school (Grade 9-10) and one repatory school (Grade 11-12). The town is mostly inhabited by Oromo and some other ethnic groups. The dominant language spoken in the town is Afan Oromo and the rest is Amharic. Protestant, and Orthodox is the dominant religion in the town and the remaining is other

The primary and secondary data source was used to carry out the study. The sources of the primary data are cross-sectional data collected from the sample that intends to represent the population. First the questionnaire is prepared. Two enumerators was selected from the study area based on two criteria-education and experience. Both the enumerators were trained for two days by the principal researcher on the administration of the questionnaire and the researcher supervisor in the data collection process. The questionnaire is designed to provide statistical information on households' demographic composition, income and expenditure, consumption and other important socio-economic information. In this survey, the question distributes to the head of the household and the responses, therefore, represent an individual's evaluation about the poverty of the entire household.

In the study area, households were the basic sampling units in order to get quantitative and qualitative data on the determinants of urban poverty. A multi-stage sampling technique was employed to get the required primary data. At the first stage, Muklami town was selected purposively because the town is severely affected by poverty. In the second stage, the household head were selected using a combination of simple and systematic sampling methods proportion to their total population size. Accordingly, from two kebele 143 households were selected through proportional random sampling techniques. The $\mathrm{K}^{\text {th }}$ household head was selected from registry frame work of kebeles by the systematic sampling technique (i.e., the $\mathrm{k}^{\mathrm{th}}=\mathrm{N} / \mathrm{n}$ ). After all, the first household was selected by lottery method, and the rest were selected by interval. 
The study used Cost of Basic needs approach (CBN). In this approach poverty line is set by taking the sum of food and nonfood costs of basic consumption basket. First the food poverty line is defined by choosing a bundle of food typically consumed by the poor. The quantity of the bundle of food is determined in such a way as to supply the predetermined level of minimum caloric requirement $(2,200 \mathrm{kcal})$. This bundle is valued at local prices (or it is valued at national prices if the desire is to get a consistent poverty line across regions and groups). Then a specific allowance for the nonfood goods consistent with the spending pattern of the poor is added to the food poverty line MoFED (2013).

Steps to establish poverty line:

Food poverty line

$>$ Stipulate a consumption bundle that is considered to be adequate for the minimum level of caloric requirement.

$>$ Pick a nutritional requirement for each food items which yield 2200 calories per person per day

$>$ Estimate a quantity of each bundle in gram that yield a calories requirement of that food items per person per day.

$>$ Then convert quantity in gram of each item consumed to kilogram.

$>$ To obtain annual adult equivalent consumption of food items multiply food items in $\mathrm{kg}$ by 365 days. Nonfood poverty line

According to World Bank (2005), there are different approaches to take part of measuring non-food poverty line practice varies widely from one analyst to the next. But most studies set the poverty line as a share of mean expenditure/income or identified the poor using some percentage (e.g. 20\%, 25\%) of the income or expenditure distribution. Therefore, in this study to account for the non-food expenditure, the food poverty line is divided by the food share of the poorest quartile or quintile (Ravallion,2003) and (MoFED,2013).Thus, accordingly, basic needs poverty line is the arithmetic sum of food poverty line and nonfood poverty line (Ravallion, 1992; Fitsum T., 2002; WBI, 2005; and Morduch J., 2006) mathematically:

$\mathrm{PL}=\mathrm{P}_{\mathrm{LF}}+\mathrm{P}_{\mathrm{LN}}$, Where PL is the poverty line

$\mathrm{P}_{\mathrm{LF}}$ is the food poverty line and

$\mathrm{P}_{\mathrm{LN}}$ is non- food poverty line

Logit model would be used when the dependent variable become dichotomous that takes values as households are poor and non-poor .In order to identify the determinants of poverty Logistic regression model would be employed. The explanatory variables are considered to be socio-economic and demographic characteristics, which includes sex, age, education, family size, income, ownership of house, health, and education of the household etc. The impact of predictor variables is usually explained in terms of odd ratio. The logistic regression of odd ratio calculates changes in the independent variable to changes in the dependent variable. After transforming the dependent variable into logit, maximum likelihood estimation would be employed to determine the coefficients of the variables. The logit method gives parameter estimates that are asymptotically efficient, and consistent. It produce statistically comprehensive result(Gujarati \& Porter, 2009)probability of being poor is specified as the value of the cumulative distribution function which is specified as function of the explanatory variables. The equation is of the form:

$Y=\alpha+\beta_{1} X_{1}+\beta_{2} X_{2}+\beta_{3} X_{3}+\ldots .+\beta_{k} X_{k}+v \imath$

$$
\beta_{i} X_{1} \text { runfrom } \beta_{1} X_{1 t} \text { to } \beta_{k} X_{K}
$$

Where,

Ý = Probability of a household being poor or non-poor

$\alpha=$ Intercept (constant) term

$\beta_{k}=$ Coefficients of the predictors estimated using the maximum likelihood method

$\mathrm{X}_{\mathrm{i}}=$ Predictors (independent variables)

$u i \quad=$ Random effect (error term)

Neurosis (1994), pointed out that, the probability of an event occurring. For the case of a single independent variable, the logistic regression model can be as follows:

$\operatorname{Pr}($ event) or equivalently $\operatorname{Pr}($ event)=------------------2

Where, $\beta$ o and $\beta 1$ are coefficient will be estimated from data, xi is the independent variable, $\mathrm{e}$ is base of the natural logarithm.

In the case of more than one independent variables:

$\operatorname{Pr}($ event $)=$ or equivalently $\operatorname{Pr}($ event)=------------------------------3

This particular study will be deal about the probability of being poor or not and this expression expressed in 
mathematical form as follows:

The probability of being poor as the forms:

$\operatorname{Pr}(\mathrm{y}=1 / \mathrm{x})=\operatorname{Pr}(\mathrm{y}=1)==$

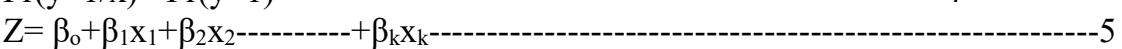

The probability of being non-poor as the form:

$1-\operatorname{Pr}(\mathrm{y}=1 / \mathrm{x})=$ $-6$

Therefore, the odds-ratio in binary response is stated as the form:

$===$ $-7$

Equation(7) is the odd-ratio in favor of household falling the poverty line. This is the poverty that a household will be poor to the probability that it will not be poor.

When we take the natural logarism of odd ratio of equation(7) is result in logit model as follow:

$\mathrm{L}_{\mathrm{i}}=$

Assumption of logistic model:

$$
Z_{i}=\beta_{0}+\beta_{1} x_{1}+\beta_{2} x_{2}+\beta_{3} x_{3}+\beta_{4} x_{4}+\beta_{5} x_{5}+\beta_{6} x_{6}+\beta_{7} x_{7}+\beta_{8} x_{8}+\beta_{9} x_{9}+\beta_{10} x_{10}+\beta_{11} x_{11}+\beta_{12} x_{12}
$$

1) Assumes a linear relationship between the logits of the independent variable and dependent variables, however, does not assume a linear relationship between the actual dependent and independent variable.

2) Independent variables were not linear functions of each other i.e. perfect multicollinearity makes estimation impossible.

3) The model was correctly specified i.e.

* The true conditional probabilities are a logistic function of the independent variables

* No important variables are omitted.

* No inessential variables are included.

* The independent variables are measured without inaccuracy.

Based on above justification, logit model for probability of being poor and non-poor and determinants of poverty was specified as follows:-

$\mathrm{Y}_{\mathrm{i}}=$

$\beta_{0}+\beta_{1}$ age $+\beta_{2}$ sex $+\beta_{3}$ fs $+\beta_{4}$ ms $+\beta_{5}$ edu $+\beta_{6}$ inc $+\beta_{7}$ hstat $+\beta_{8}$ htenu $+\beta_{9}$ savhab $+\beta_{10}$ accscred $+\beta_{11 \text { watsour }}+\beta_{12}$ empstat $+\mathrm{ei}-$ 9

Therefore, $\mathrm{yi}=1$ if household is poor and $=0$ if household is not poor, $\beta \mathrm{i}$ is parameters, ei is the error term and explanatory variables will be defined under the next section of variable description.

\section{DATA ANALYSIS AND DISCUTION}

In this section, the socioeconomic and demographic characteristics of the data obtained in household survey of Muklami town are described. The whole description takes total poverty line (food plus nonfood consumption expenditures) as a reference to identify the poor from the non-poor households. Descriptive and econometrics analysis of the data is made. In the first part, the result of descriptive statistics will presented and then the result of econometrics will be presented.

\section{Setting poverty line.}

Food poverty line:

$>$ Total adult equivalent food expenditure $=2637882$ Birr

$>25 \%$ Adult equivalent population food share $=48063.5 \mathrm{Birr}$

$>$ Percentage share of the lowest $25 \%$ population $=0.018220489$

$>$ Food poverty line $=2965.83214$ Birr

Non-food poverty line: is the ratio of food poverty line to the share of lowest 25 percent of expenditure distribution. Accordingly:

$>\quad$ Non-food poverty line $=2965.83214 / 1.8220489=1627.745633$

Therefore, poverty line in the study area $=$ food poverty line plus non-food poverty line $=2965.83214+1627.745633=4593.577773$

As the data obtained in this study showed, from the total 143 household survey in Muklami town 51(35.66\%) households was below poverty line(poor) and 92(64.34\%) of the households are above the poverty line(non-poor).

Head count index (po):

This is the proportion of the population whose measured standard of living (consumption) is less than the poverty line i.e. The share of population that cannot afford to buy a basic basket of good either food or non-food with the stated amount.

$\mathrm{Po}=$ $-10$

Where $\mathrm{Np}=$ number of households below a given poverty line $\mathrm{N}=$ total number of household in the sample size 
$\mathrm{Po}=$ poverty head count index

Therefore,

Po $=51 / 143=0.3566$

The results show that, out of the total surveyed households, $35.66 \%$ of the households were below the poverty line. It is greater than the national poverty of the country and Oromia regional state which is $33.60 \%$ and $28.90 \%$ respectively CSA $(2010 / 11)$.

Poverty gap index $\left(\mathrm{p}_{1}\right)$ : it defines the short fall of the poor from the poverty line, which gives an indication of the aggregated gap between those individuals or households that are poor and the determined line that is needed to reach out of poverty.

$\mathrm{P}_{1}=1 / \mathrm{N}$, for $\mathrm{i}=1,2,,,,,, \mathrm{q}$ individual or household equation, where

$\mathrm{N}=$ sample size

$\mathrm{Yi}=$ the consumption for individual household

$\mathrm{Z}=$ poverty line

Therefore, using the index function we have

$1 / 143(18.187607936)=0.127$

The result shows the consumption short fall of poor to reach poverty line is 12.7 percent. It is greater than the national poverty gap index which is $0.078(7.8 \%) \operatorname{CSA}(2010 / 2011)$. Therefore, it estimates the total resources needed to bring all the poor to the level of the poverty line consumption or the town needs to mobilizes resources equal to 12.7 percent of the poverty line for every adult equivalent individuals and distributes these resources to the poor in the amount needed so as to move them to poverty line.

Poverty severity or squared poverty gap $\left(\mathrm{p}_{2}\right)$ : this index takes in to account inequality among the poor, it is simply a weighted sum of poverty gaps, and hence, by squaring the poverty gap index, the measure implicitly puts more weight on observations that fall well below the poverty line.

$\mathrm{P}_{2}=1 / 143$

$1 / 143 *(=0.05088$

Even though households, whose consumption expenditure line below poverty line have common name "poor" the degree of poverty varies from one to another. Therefore, poverty severity index measures variation in the poverty level of individual households. The result indicates 5.08 percent variation among poor households in the study area. It is greater than the national poverty severity which is $0.031(3.1 \%)$ CSA $(2010 / 2011)$.

Poverty and household socioeconomic characteristics

In this study, the poor household average family size was 6.00 and a non-poor household is 4.5 . The results are shows the poor households have larger family than non-poor households. Therefore, it is terrific clue to know the demographic factors influence on prevalence of poverty.

Table 2: Households age and sex composition and their economic activity

\begin{tabular}{|l|l|l|l|l|l|l|l|l|l|l|l|}
\hline Poverty & \multicolumn{3}{|l|}{ Household heads } & \multicolumn{3}{l|}{ Economic activity } & \multicolumn{2}{l|}{$\begin{array}{l}\text { Family } \\
\text { member }\end{array}$} \\
\hline & male & female & total & working & $\begin{array}{l}\text { Not } \\
\text { working }\end{array}$ & total & $0-14$ & $\begin{array}{l}15- \\
64\end{array}$ & $>64$ & Male & female \\
\hline Poor & 25 & 26 & 51 & 105 & 198 & 303 & 168 & 93 & 42 & 158 & 145 \\
\hline Non poor & 62 & 30 & 92 & 264 & 120 & 384 & 67 & 291 & 20 & 209 & 175 \\
\hline
\end{tabular}

Source: own survey, 2017

From the total surveyed households there are 369 working and 318 not working family members which are $46.29 \%$ of the family members were not working. Out of 303 family members living in poor households 198 were not working and 105 working i.e about $65.35 \%$ were not working. Where as in non-poor only $31.25 \%$ were not working.

\subsection{Description of socioeconomic characteristics}

The descriptive analysis of data was show the poverty level in different demographic structures, extent and proportion of poverty due to differences in urban households by using percentage, tables and other if necessary.

Age and Poverty

According to Mekonnen(2002) and Grootaert(1997), found out that the probability to be poor decreases as the age of the household head increases. 
Table 3: The distribution age of households

\begin{tabular}{|c|c|c|c|c|c|c|}
\hline \multirow{2}{*}{$\begin{array}{l}\text { Age } \\
\text { category }\end{array}$} & \multicolumn{2}{|l|}{ poor } & \multicolumn{2}{|c|}{ Non-poor } & \multicolumn{2}{|l|}{ total } \\
\hline & number & $\%$ & Number & $\%$ & number & $\%$ \\
\hline $18-30$ & 11 & $21.57 \%$ & 47 & $51.09 \%$ & 58 & $40.56 \%$ \\
\hline $31-60$ & 32 & $62.74 \%$ & 42 & $45.65 \%$ & 74 & $51.74 \%$ \\
\hline Above 60 & 8 & $15.69 \%$ & 3 & $3.27 \%$ & 11 & $7.70 \%$ \\
\hline Total & 51 & 100 & 92 & 100 & 143 & 100 \\
\hline Mean & 45.86275 & & & 9.474855 & & \\
\hline Std. Dev & 14.00574 & & & 2.11838 & & \\
\hline
\end{tabular}

Source: Own survey, 2017 Significant at 5\%*

In the study area, age negatively correlated with poverty and is significant at $5 \%$. This indicates, as age increases urban households would acquire knowledge and experience through continuous learning. Particularly, at old age household had hold most important asset (i.e. house, and domestic animals such as cow, goat, sheep, horse, mule, donkey and etc.) and became a member of social security (i.e. Edir) which help them to escape from poverty. This result has conformity with Vincent O'sulliv and Richard Layte(2002, pp 261) the older people are income poor but asset rich compared with younger people.

\section{Poverty and Family Size}

The result of the survey revealed that household family size is positively correlated with poverty. The $t$-test $=3.77$ and significant at $10 \%$ level of significant. The minimum and maximum household size of the study area was 1 and 15 respectively. The average household size was 5.23 members per households. As shown in the Table 3 below, the share of poor households within the category of household size five and below were $45.10 \%$ of the total poor. Households that have household size of above the average family size takes the high share, is $54.90 \%$ of the total poor. Therefore the majorities of households in the study area, who have greater than average family size and above are live below poverty line. This shows household family size and poverty has positive relationship. As household family size increases the probability to being poor is increases.

Table 4: Distribution of Sample Household by Family Size

\begin{tabular}{|c|c|c|c|c|c|c|}
\hline Households & Poor & $\%$ & Non poor & $\%$ & total & $\%$ \\
\hline Below five & 23 & $45.10 \%$ & 62 & $67.39 \%$ & 85 & $59.40 \%$ \\
\hline Above five & 28 & $54.90 \%$ & 30 & $32.61 \%$ & 58 & $40.60 \%$ \\
\hline total & 51 & 100 & 92 & 100 & 143 & 100 \\
\hline Mean & 5.941179 & \multirow{3}{*}{\multicolumn{2}{|c|}{$\begin{array}{l}4.521739 \\
1.769573\end{array}$}} & \multirow{3}{*}{\multicolumn{3}{|c|}{$\begin{array}{l}5.231459 \\
2.094794\end{array}$}} \\
\hline St.Dev & 2.420015 & & & & & \\
\hline T.value & 3.77 & & & & & \\
\hline
\end{tabular}

Source: Own survey, 2017 significant at 10\%

\section{Income of households and poverty}

The households' income starts from birr (380) minimum to birr $(10,000)$ maximum per months. Out of this mean income of poor is 959.1765 birr and non-poor households, 2712.35 birr per month. There are high different between income of the poor and non-poor in the study area. The ttest-values $=4.74$ and significant at $1 \%$ level of significant.

Table 5: Income of households

\begin{tabular}{|l|l|l|l|}
\hline Group & Observation & Mean & St.Dev \\
\hline Poor & 51 & 959.1765 & 1043.70 \\
\hline Non poor & 92 & 2712.35 & 177.354 \\
\hline Total & 143 & & \\
\hline t-values & \multicolumn{3}{l|}{} \\
Std.Err & 4.74 & & \\
\hline
\end{tabular}

Source: own survey, 2017 significant at 1\%

\section{Poverty and Education of Households}

The study area education of household head negatively correlated with poverty and is significant at $10 \%$. This indicates, as the educational level of the household's increases, their probability of falling to poverty decreases and vice versa. Tables 6 shows, non-poor household's increases from lower education level to the higher level and 
vice versa. When we see the proportional sample respondent fall below poverty line by their educational level; illiterate (21.57\%), primary (1-8) (35.29\%), Secondary (9-12) (29.41\%), Diploma \&Certificate (9.80) and Degree and above $(3.92 \%)$. Thus, the outcome of the survey shows that numbers of non-poor households increases as the household educational attainment became higher. Szekely (1998), Cortes (1997) and Esubalew (2006) found that education is negatively correlated with poverty in his study in Debra markos.

Table 6: The distribution households' educational level

\begin{tabular}{|l|l|l|l|l|l|l|}
\hline Education level & Non poor & \multicolumn{2}{l|}{ Poor } & \multicolumn{2}{l|}{ Total } \\
\hline & Number & $\%$ & Number & $\%$ & Number & $\%$ \\
\hline Illiterate & 7 & $7.61 \%$ & 11 & $21.57 \%$ & 18 & $29.18 \%$ \\
\hline $1-8$ & 10 & $10.87 \%$ & 18 & $35.29 \%$ & 28 & $46.16 \%$ \\
\hline $9-12$ & 26 & $28.26 \%$ & 15 & $29.41 \%$ & 41 & $57.67 \%$ \\
\hline Diplom\&cert & 28 & $30.43 \%$ & 5 & $9.80 \%$ & 33 & $40.23 \%$ \\
\hline Degree\&above & 21 & $22.83 \%$ & 2 & $3.92 \%$ & 23 & $26.75 \%$ \\
\hline Total & 92 & $100 \%$ & 51 & $100 \%$ & 143 & $100 \%$ \\
\hline
\end{tabular}

Source: Own survey, 2017 significant at $10 \%$ level

\section{Employment and poverty}

Empirical studies indicate that employment has a high and negative correlation with poverty (Maru, 2006). However, few research works infer that there is significance difference between the unemployed heads and these who are employed in the informal sector (NIS, 2007).

Table 7: Employment status of households and poverty

\begin{tabular}{|l|l|l|l|l|l|l|}
\hline Poverty & Poor & $\mathbf{\%}$ & Non-poor & $\mathbf{\%}$ & total & $\%$ \\
\hline Employed & $\mathbf{1 6}$ & $\mathbf{3 1 . 3 7 \%}$ & $\mathbf{6 4}$ & $\mathbf{6 9 . 5 7}$ & $\mathbf{8 0}$ & $\mathbf{5 5 . 9 4}$ \\
\hline unemployed & $\mathbf{3 5}$ & $\mathbf{6 8 . 6 3}$ & $\mathbf{2 8}$ & $\mathbf{3 0 . 4 3}$ & $\mathbf{6 3}$ & $\mathbf{4 4 . 0 6}$ \\
\hline Total & 51 & 100 & 92 & 100 & 143 & 100 \\
\hline
\end{tabular}

Source: own survey 2017, significant at $\mathbf{1 0 \%}$ ).

As table 6 depicts, employment and probability of being poor negatively related and the coefficient is different from zero at 90 confidence level. The employment categories of the respondents are classified into two major classes, these are Employed (55.59\%) and Unemployed (44.06\%), $\mathrm{P}>\operatorname{ch} 2=0.0782$ shows there is a statistically significant difference at $\mathbf{1 0 \%}$ level of significance. That indicates that employment status determine the status of poverty in the study area.

\section{Water source and poverty}

The provision of purified water is becoming a critical issue for urban dwellers without which life will be difficult. A provision of purified and easily accessible water is negatively correlates with poverty. This is, of course in the study area. The water source of respondents are classified into two major classes, these are: household who have their own private tap, and have no their own private tap.

Table 8: Households' source of water supply

\begin{tabular}{|l|l|l|l|l|l|l|}
\hline Water source & Poor & $\%$ & Non poor & $\%$ & total & $\%$ \\
\hline private tap & 17 & $33.33 \%$ & 56 & $60.87 \%$ & 73 & $51.05 \%$ \\
\hline No tap & 34 & $66.67 \%$ & 36 & $39.13 \%$ & 70 & $48.95 \%$ \\
\hline Total & 51 & 100 & 92 & 100 & 143 & 100 \\
\hline
\end{tabular}

Source: own survey 2017 , significant at $\mathbf{1 0 \%}$

In the table above, out of the total surveyed, $60.87 \%$ of the non-poor households have their own private tap, and $33.33 \%$ of poor households. $\mathrm{Ch} 2=0.02$, shows there is a statistically significant difference at $\mathbf{1 0} \%$ level of significance. Therefore, the finding of this study shows poverty is higher for households who have not private tap than those who have their own private tap. This calls for concerned bodies to curb the problem of water source of the town.

\section{Summary of Explanatory Variables}

Table 9 below provides the summary of means and standard deviations of the household scores of the two groups on some discrete variables and continuous variables. Non poor and poor households' differ appreciably with respect to various interval-scaled socioeconomic variables. Out of 3 continuous variables, non-poor and poor households differ significantly in all of them and out of 9 discrete variables; non-poor and poor groups were significant with 3 of them. Accordingly, t-tests and chi-square tests were used to substantiate the presence or absence of differences between the two groups' poor and non-poor households and the value for each variable were presented in the respective. 
Table 9: Summary statistics of continuous variables

\begin{tabular}{|l|l|l|l|l|l|}
\hline & \multicolumn{2}{l|}{ Non-poor households } & \multicolumn{2}{l|}{ Poor households } & \\
\hline Variable & Mean & Std. Dev. & Mean & Std. Dev. & T.test values \\
\hline Age & 33.09 & 10.23 & 45.86 & 14.01 & 10.71 \\
\hline Fs & 4.52 & 1.77 & 5.94 & 2.42 & 3.77 \\
\hline Edu & 3.50 & 1.18 & 2.39 & 1.06 & 4.32 \\
\hline Incom & 2712.4 & 1775.35 & 956.18 & 1043.76 & 4.74 \\
\hline
\end{tabular}

Source: Own survey 2017

Table 10: Summary statistics of discrete variables

\begin{tabular}{|l|l|l|l|l|l|}
\hline & Non-poor households & \multicolumn{2}{l|}{ Poor households } & \\
\hline Variable & Mean & Std. Dev. & Mean & Std. Dev. & Ch-square \\
\hline sex & 0.32 & 0.47 & 0.50 & 0.50 & 0.55 \\
\hline Ms & 1.61 & 1.07 & 2.11 & 1.21 & 0.76 \\
\hline Hstatu & 0.32 & 0.47 & 0.54 & 0.50 & 0.13 \\
\hline Htenure & 0.40 & 0.49 & 0.56 & 0.50 & 0.43 \\
\hline Empstat & 0.69 & 0.46 & 0.31 & 0.46 & 0.04 \\
\hline Watsource & 0.60 & 0.49 & 0.33 & 0.47 & 0.02 \\
\hline Savhabit & 0.37 & 0.48 & 0.49 & 0.50 & 0.53 \\
\hline Credit & 0.45 & 0.50 & 0.56 & 0.50 & 0.73 \\
\hline
\end{tabular}

\subsection{Econometric Results}

As introduced in the model specification part, a Logit model was employed to analyze determinants of poverty. This model is appropriate when we assume the random components of response variables follow binomial distribution \& when most variables are categorical responses. The suitability of the chosen model for econometric analysis very much depends on how much it predicts from the actual observation or what percent of the actual observation is really predicted by the model. There are no fixed points as to judge the model as a best or bad predictor yet it is generally agreed that a model with its overall predictive power of three percent or more is good (Mangus et al., 2006). Therefore, to assess whether or not the model fits the data, the researcher used different tests.

\subsubsection{Model Goodness and diagnostics test results}

Goodness of the model: The result of $\mathrm{LR} \mathrm{Chi}^{2}(12)$ value is statistically significant at $1 \%$ percent level of significance. This shows that the model have good explanatory power in explaining the data. In addition, Hosmerlemshow goodness- of -fit statistic is also computed to a test a good fit of the model as measured indicating a large p-value. Therefore, the result shows that the model fit the data well (see appendix 5).

Multicollinearity: Is the situation in which the explanatory variables are highly correlated or show little variation between them. In cross sectional data the problem of multicollinearity is a serious problem to checks this VIF computed. If the VIF values for continuous variable equal to 10 or greater than 10 there is an association between continues variables have problems of multicollinearity. But in this research the average VIF is 1.82 i.e. it is less than 10 therefore, there is no serious multicollinearity problems (see, appendix 4). The values of VIF for discrete variables were found to be checked using contingency coefficient (see, appendix 3). Based on the result, the data have no serious problem of multicollinearity.

Heteroscedasticity test: A situation in which the variance of the dependent variable varies across the data. Many methods in regression analysis are based on the assumption of homoscedasticity or equal (homo) spread (scedasticity), that is, equal variance (Gujarti, 2004). In logit analysis there is no equal variance or homogeneity of variance assumptions and the variance of the error terms is not constant. In this analysis, Cook Weisberg test for heteroscedasticity (hettest) using fitted values of poverty is carried out in STATA software. The result of Chisquare $(1)=3.10$, Prob $>\operatorname{ch} 2=0.0782$. Thus, the dependent variable varies across the data. 
Table 11: Logistic regression result

\begin{tabular}{|l|l|l|l|l|}
\hline Variables & Coef. & Std. Err. & Z & Odd ratio \\
\hline Age & $-0.05^{* *}$ & 0.020 & 2.52 & 1.05 \\
\hline Sex & .031 & 0.577 & 0.54 & 1.36 \\
\hline Fs & $0.25^{*}$ & 0.146 & 1.76 & 1.29 \\
\hline Ms & -0.21 & 0.272 & -0.79 & 0.80 \\
\hline Edu & $-0.40^{*}$ & 0.236 & -1.70 & 0.66 \\
\hline Income & $-0.001^{* *}$ & 0.0003 & -2.85 & 0.99 \\
\hline Hstatu & 0.57 & 0.560 & 1.03 & 1.77 \\
\hline htenure & 0.35 & 0.547 & 0.65 & 1.42 \\
\hline Empstatu & $-1.02^{*}$ & 0.573 & 1.79 & 0.36 \\
\hline Watsource & $-1.09^{* *}$ & 0.554 & 1.98 & 0.33 \\
\hline Savhabit & -.53 & 0.575 & -0.93 & 0.58 \\
\hline Credit & -.28 & 0.554 & -0.51 & 0.75 \\
\hline -cons & -2.04 & 1.777 & -1.15 & 1.08 \\
\hline LR Chi ${ }^{2}(12)$ & $85.17^{* * *}$ & & & \\
\hline Pseudo R & $45.71 \%$ & & & \\
\hline
\end{tabular}

Source: Model result, $2017 * * *, * *$ and* are significant at $1 \%, 5 \%$ and $10 \%$.

The variable that are negatively correlated with the probability of being poor are marital status, employment status, water source, education, income, saving habit, and access to credit. Positively correlated with the probability of being poor were age, sex, family size, house tenure, and health status. In the table 8 above of 12 independent variables, six of the variables age, family size, education, income, employment status and water sources have a significance level at $1 \%, 5 \%$, and $10 \%$. The negative values of explanatory variables indicates that when the unit change in independent variable lead to decrease in probability of being poor.

The family size has positively and statistically significant in affecting the probability of poverty at $10 \%$ level of significance. The positive relationship indicates that, the probability of being poor increases with an increase in the family size. This is due to the clear fact that the numbers of the children age less than 15 were larger in poor households than non-poor households, less job opportunity, member of the family become unemployed and tied with low rate of payment. The odds of getting out of poverty for households who have small family size 1.29 times that of the probability of getting out poverty for those households who have large family size.

Level of Education of the household head has negatively and statistically significant effect on the probability of poverty at $10 \%$ level of significance. This implies, when an individual gets better educational attainment the productivity, skill, bargaining power and competitiveness of the individual in the labor market as well as in the social system become higher. This helps households to earn more income and reduces the probability to be joined to the poorer. The odds of getting out of poverty for households who are better educational status have 0.66 times that of the not educated. The most empirical studies on poverty concluded that education has a negative impact on poverty but the degree of influence differs depending on the socioeconomic situation in which the study is carried out(Alemayo ., et al., 2005; Esubalew, 2006).

Water source has negatively and statistically significant effect on the probability of being poor at $5 \%$ level of significance. The negatively relationship indicates that, the probability of being poor decrease with an increase in the private tap. The odds of getting out of poverty for households who have private tap are 0.33 times that of no private tap. This implies having private tap has negative impact for households to be out of poverty in particular and important for the whole population of the town to support the fight against poverty.

The income of household has negatively and statistically significant affection on the probability of being poor at $1 \%$ level of significant. This implies income has negative impact for households to be out of poverty in particular and important for the whole population of the town to support the fight against poverty. The odds of getting out of poverty for households who have high income are 0.99 times that of low income. This outcome confirmed by Alemayo et al (2005) in Kenya,Getachew(2009) in Gondar and et,al (2009).

\section{SUMMARY, CONCLUTION AND RECOMMENDATION}

\subsection{Summary and Conclusion}

The objective of the study was to examining determinants of household poverty and its relationships up on urban poverty in Muklami town. Both primary and secondary sources were used to carry out the study. A total of 143 household heads were randomly selected. The proportional random sampling was used to select households from the two kebeles based on registration.

The research used the cost of basic needs approach in the identification of the poor from the non-poor. $2200 \mathrm{kcal}$ as the minimum calorie required per adult per day in Ethiopia. Based on this approach the study found out of 143 surveyed households $51(35.6 \%)$ of them are found below the poverty line. Variables, which we 
attempted to analyze household poverty in terms of household specific were selected and analyzed. These were income, education, sex, age, family size, employment status, saving habit, house tenure, water sources and access to credit were analyzed. These variables were analyzed through descriptive statistics and Econometrics model. A Logit model was used to compute the relationship between some selected determinants and poverty.

In the descriptive part analysis was made by making use of STATA software 12 version .In this parts categorical response were treated via percentages, Chi-squares and significance levels with the help of tables. Whereas continuous variable analyzed by standard deviation, and t-tests. In the econometric part the study employed the Logit model. The coefficient which tells by what factor does the dependent variable change given a unit change of the explanatory variable was also discussed. Odd ratio and significances of each explanatory variable were computed.

Based on the descriptive and econometric analysis the following results were obtained. Educational attainment of the household head is found to be most important variable that related with urban poverty. The econometrics regression/ logit model also revealed that education and poverty are significance at $\mathbf{1 0 \%}$ and negatively related, implying that education is determinant factor to alleviate household poverty in the study areas.

Average household size of the study area was found to be 5.94 per household. The number of poor households who have five and below household size were very few but households that have household size of above the five takes the high share, which is $54.90 \%$ of the total poor. The model estimation of the variable household size has been positive and significantly correlated with poverty. This has a clear effect for the residents of with large households size pushes to fall into the poverty trap easily than those who have average and small family size.

Income of households and probability of being poor are found a significant negative correlate. When the income of a household increases the probability of households to poverty trap is diminishes significantly. Though income only is not measure of poverty, the study found households that lack income were also in shortage with other resources like house, education attainment, and water sources. The result of incidence of poverty based on CBN indicates that $35.6 \%, 12.70 \%$ and $5.08 \%$ of $\mathrm{P}_{0}, \mathrm{P}_{1}$ and $\mathrm{P}_{2}$ respectively calls for urgent interventions aimed at curbing the chance of the poor.

In general, it is concluded that urban poverty is multidimensional and has interrelated factors. One cause of poverty may become a consequence in other side. That means one variable may be a cause and consequence simultaneously. Critical identification of the variables is important for direct and concrete solutions. Therefore, urban poverty can be alleviated through multiple strategies that affect the poverty situation of household in different direction.

The Incidence of poverty among the study areas households $0.3566(35.66 \%), 0.127(12.70 \%), 0.0508(5.08 \%)$ headcount index, poverty gap, and severity index respectively calls for designing poverty alleviation mechanism aimed at curbing the fortune of the poor. One way of remedies is studying the determinants of urban poverty by informing concerned parties as the factors are important in fighting against poverty. Without the clear identification of the determinants of urban poverty it is really difficult to improve the life in the town and to come up with concrete solution.

\subsection{Recommendation}

- Education is an important determinant of household poverty in the study area. Households with higher education level have a lower probability of falling into poverty. Thus, promotion of education is central in addressing problems of poverty in the town. Specifically, college, TVT, and university is found to be a principal in reducing poverty in Muklami town. Households headed those who have first degree and above did not fall in poor category. In general, the creation of human capital in the shape of better education increases the productivity/income of the poor. Therefore government, city administration and society should be emphasis to establish college and university in the towns.

- Household family size was positively and significantly correlated with poverty in Muklami town. This has a clear implication for the residents of the town in that households with large size fall in poorer sections of poverty easily than those who have not. Thus, to overcome this problem family planning should be exercised and taken as a remedial measure by the concerned bodies. This calls for overall town's health extension services in general and focus on poor households in particular.

- In the study area, water source influences poverty and statistically significant variables. Most of poor households are collect water from public water distribution center, river and spring. Woman and children walk up to one hours to collect water from unprotected ponds which the share with animals. So, it's time inflated and chance is more to poor households for water borne diseases. On other hands, the old project constructed by government was unable to drive the water demand of the town. Because, as number of population increases the demand of water also increases. The better water supply and sanitation is important to reduce excessive time spent collecting water, to reduce cost of health services especially for water related disease. Therefore, to improve the water source related problem of the town, the government should construct new project and expand water connection line and distribution and Muklami water supply office can take the initiative in 
collaboration with financial institutions.

- Poverty alleviation efforts should be made through the grass root planning to raise real incomes of residents. This can be done through steady job creation, develop and promote micro and small-scale enterprises relating to households skill and market opportunities ,efforts should be made for households to acquire credit based on real situation of the society, so as to generating income and creating employment opportunity. On other hands, supporting households to have own house should another remedial measure to minimize rent of house service. This can be in the form of free and fast land delivery for housing construction, affordable credit facility, building the condominium house. Therefore it require the companied efforts of governments, town administration and micro finance institutions should be needed. Hence, microfinance activities will go hand in hand with entrepreneurship enabling the poor to borrow for production purposes, save and build their assets and as a result poverty will be reduced.

- The poverty incidence of muklami town found to be very high, though the incidence was found greater than the Ethiopian urban poverty incidence. Therefore, the town administration and other stake holders have to take measures on the determinant factors to hamper the poverty at the town as well as household level.

- Finally all these will help to reduce, if not completely eradicate of poverty in the town. Therefore, a joint effort is needed at every level and kind of activities from the government, non-governmental, community based organizations, researchers, the poor themselves, and from any interested stakeholder(s).

\section{REFERENCES}

Alemayehu et al, (2005).Determinants of Poverty in Kenya: A Household Level Analysis Universityof Connecticut, Department of Economics, Working Paper 2005-44.

Aray (2013), Poverty and Income Enequality in Urban Areas: The socio Economic Analysi of Households in Wukro Wereda.

Chen S., and Ravallion M., (2008). The Developing World Is Poorer Than We Thought, But No Less Successful in the Fight against Poverty

CSA (2007). The Population and housing censes of Ethiopia, Addis Ababa, volume 1 Dercon,S.,(1999), Ethiopia Poverty Assessment Study http://www.econ.ox.ac.uk/members/stefan.dercon/IFAD1.pdf.

Muklami town Administrative (2012). Preliminary Study on the Socioeconomic Status of Of the Town (unpublished, translated Version)

Muklami City Administration Strategic Plan (2009- 2014) Unpublished (Oromic version)

Esubalew (2006). Determinants of Urban poverty: the Case of DebreMarekos, Ethiopian Economics Association Proceeding of the fifth International Conference on the Ethiopian Economy, volume two, P. 37 -60. Addis Ababa, Ethiopia.

Eyob and Haris, M (2001) .Modeling Determinants of Poverty in Eritrea: a new Approach, Monash University, Australia

Food and Agriculture Organization -UN (2006) State of Food Insecurity in the World Accessed at http://www.fao.org/docrep/009/a0750e/a0750e00.htm

Foster, J, Greer.J, and Thorbecke, E (1984).” A class of Decomposable Povert Measures.”econometric 52

Getachew,(2009), Determinants of households Poverty:The case of Gondar city.

Gujarati D., (2004) Basic Econometrics. Fourth Edition, New York, McGraw-Hill,Inc.

Garza. (2001). The Determinants of Poverty in Mexico

Human Development Report 2003, New York, Oxford University Press. Accessed at Http://hdr.undp.org/en/reports/global/hdr2005/(2006).Human Development

Report, 2006 Accessedathttp://hdrundp.org/en/reports/global/hd2006

Kedir, A and McKay, A (2003). Chronic Poverty in Urban Ethiopia, paper prepared for International Conference on "Staying Poor: Chronic Poverty and Development Policy". Manchester, UK, 7 - 9 April 2003.

Kedir and McKay (2003 chronic poverty in urban Ethiopia: panel data evidence. International Planning Studies, Volume 10, Number 1

Magnus, A., Anders E. and Ari K., 2006. Determinants of Poverty in LAOPDR, Working Paper223, Stockholm, Sweden.

Maru S.,2004.Rural poverty and its determinants in Zegher Peninsula, Bahirdar Zeria wereda,Master's thesis, Addis Ababa University, Addis Ababa, Ethiopia.

Metalign, A. T., 2005. Rural Poverty Situation and Determinants: The Case of Kersa Kondality Wereda, South West Shewa, Master's Thesis, Addis Ababa University

Ministry of Economic Development and Co-operation - MEDAC (1999) Poverty Situation in Ethiopia, Welfare Monitoring Unit, Addis Ababa Ministry of Finance and Economic Development (2002), Ethiopia. Sustainable Development and Poverty Reduction Program (Draft). Addis Ababa.

Mohammed T. (2009), Determinants of Household Poverty: the case of Woldia town, M.AThesis, Ethiopian Civil Service Collage Urban Management Masters Program unpublished. 
MoFED, (2002), Development and Poverty Profile of Ethiopia, Welfare monitoring unit, Addis Ababa Ethiopia MoFED, (2007), Annual Progress Report of 2005/06. Addis Ababa

MoFED, (2013), Development and Poverty in Ethiopia 1995/6-2010/11, p. 2-3. Addis Ababa

PASDEP (2006), Plan for Accelerated and Sustainable Development to End Poverty (2006-2010), Addis Ababa Ethiopia

Revallion, (1992) Poverty Comparisons: A Guide to Concepts and Methods. LSMS Working Paper No, 88, Washington, D.C,

Ravallion, M and B. Bidani. (1994) 'How robust is a poverty profile?'

Sallila S. and Hiilamo, H.2004.Rethinking Relative Measures of Poverty, Working Paper No.368, Maxwell School of Citizenship and Public Affairs, Syracus University

T.Y.Mok et.al (2007) Determinants of Urban Household Poverty in Malaysia, accessed at http://www.scipub.org/fulltext/jss/jss34190-196.pdf

Tadesse (1999). “Determinants and Dynamics of Urban Poverty in Ethiopia.Ethiopian Journal of Economics 8, no. 1: $61-82$

Tesfaye, A (2006).The Analysis of Urban Poverty in Ethiopia, University of Sydney, Australia United Nations Development Programme (UNDP) (2003). 